exactly the same way as a fractured bone, which is planned for the very opposite. The Grand Palais, Paris, lays itself out, amongst other things, for the special treatment of joints stiff as the result of bad treatment, and it is estimated that in six months it has saved $£ 644,000$ in pensions and gratuities, and similar institutions are rapidly springing up in this country, on the staff of one of which I hold an honorary position.

My object in bringing the matter before your readers was to induce those who were still practising timorously on the old lines to view their cases in the proper perspective, and I am still hopeful that the number of medical men who unwittingly, but none the less culpably, "manufacture" those cases for us may yet be gradually diminished.

I am, Sir, yours faithfully, JoHN Collie, M.D., C.M.

Porchester-terrace, W., August 24th, 1916.

\section{A SERIOUS FLAW IN THE RETAIL DISTRIBUTION OF MILK.}

\section{To the Editor of THE LANCET.}

SIR,-Twice recently within a fortnight milk purporting to be " nursery milk" was left at my house in a dirty bottle. This was obvious from the fact that when the milk was poured out the bottom of the bottle was found to be crusted inside with dirty, dried milk. I may mention that the milk was furnished by one of the large London dairy companies. On a complaint being made to the manager of the local branch the girl who brought the milk round confessed that she had given someone else the nursery milk intended for us and had filled a dirty bottle collected from another house with milk from the churn and left it with us as nursery milk. When an allowance is made for the dislocation of labour consequent upon the war, it is disquieting to think that our infants are liable to be exposed to such grave risks as are incurred by the procedure above mentioned. It makes one shudder to think of the myriads of bacteria there may be in the bottom of a dirty, unwashed milk-bottle which has stood in somebody's area or back garden, possibly for twelve or more hours, and as often as not in close proximity to a dust-bin or water-closet, and then to think of a pint of milk being put into such a bottle and left at one's house as food for an infant! If such a condition of things obtains in a good residential district where the price of nursery milk is $6 d$. or even $7 d$. a quart, it is no wonder that our children's hospitals are flooded with cases of gastro-enteritis from the poorer quarters, especially at this season of the year. Doubtless every week hundreds of infants are stricken down, many of them never to rise again, by the criminal practice of putting their milk into dirty bottles. This, too, when it is of the utmost importance to the future welfare of the nation that as many infant lives as possible, and especially the lives of male infants, should be preserved to make up for the terrible wastage due to the war.

When I interviewed the secretary of the company with reference to my complaint, he admitted that it was a serious matter, but that he could not easily prevent it, although instructions were given to men and girls who distributed the milk that they were on no account to fill dirty bottles with milk from the churns. He asked me what I could suggest to prevent it. In the first place, I would suggest that all persons concerned in the distribution of milk should receive elementary instruction in the potentialities for evil inherent in dirty milk, especially to infants and young children. Secondly, the filling of dirty bottles or cans collected from houses should be absolutely forbidden, and it should be impossible for anyone but an authorised person to have access to the cardboard dises with which the bottles are closed. Thirdly, bottles or cans with " nursery milk" should be filled only at the dairy and sealed with some sort of label to which again only an authorised servant of the company should have access. Fourthly, I would suggest that it should be made a punishable offence for anyone to put milk, and especially milk intended for the food of infants, into a dirty bottle, and that notices to that effect should be prominently displayed in every dairy.

Another point in this connexion which is of importance. The company in question, so the secretary informed me, was pasteurising $a l l$ the milk (general and nursery milk) it was supplying to customers, yet this milk was described as "fresh cow's milk." Customers should be informed when milk is pasteurised, otherwise there is the possibility that it will be boiled again (milk is always boiled in my own household), with the result that infants fed on twice-sterilised milk run the risk of developing scurvy.

The importance of this subject and the need for an urgent solution are my excuse for writing to you at such length.

Harley-street, $\mathbf{w}$ I am, Sir, yours faithfully,

DAVID NABARRo.

\section{THE EFFECT OF FRESH HUMAN BLOOD SERUM ON ARTIFICIAL MEDIA.}

\section{To the Editor of THE LANCET.}

SIR,-In their paper on this subject published in THE LANCET of August 19th, Lieutenant-Colonel L. S. Dudgeon, Mr. F. Bawtree, and Dr. D. Corbett throughout use the term "fresh human serum." They do not, however, give any evidence that there is any special advantage in the serum being freshly drawn. We have, in common with many others, used unheated human serum as an addition to artificial media for a considerable number of years, but our experience has been that the growth of the various pathogenic bacteria is better if the serum used is not quite fresh but has been drawn for a period of a week or so before use. After this time it may be used for many months without appearing to lose its value for enriching media. As evidence of this we may mention that ten years ago when one of us (G. T. W.) was doing a considerable number of opsonic indices with the gonococcus, unheated serum, hydrocele or ovarian agar was used, and it was found to be possible to plant a culture at $10 \mathrm{~A} . \mathrm{M}$. and use it the afternoon of the same day. The serum used here was used from seven days to nine months after it had been collected. Serous exudates, such as ascitic fluid or pleural fluid, which are liable to contain numerous cells, are not in our experience as valuable as serum or clear hydrocele or ovarian fluid. The cells or cell extracts possibly produce an inhibitory effect on pathogenic bacteria.

We think, therefore, that the important factor is the avoidance of heating and not the freshness of the serum. This, however, is a point which, it appears to us, has for years been well recognised by most bacteriologists and has repeatedly been emphasised on numerous occasions. Bumm in 1885, and again Wertheim in 1890, described in detail the method of making up unheated human serum agar in slopes and plates, and showed its value as a medium for the growth of some more delicate bacteria; since then the use of unheated human serum for growing gonococci has been almost a commonplace in bacteriology; it has also been used to enhance the virulence of various bacteria. Recently the epidemics of cerebro-spinal meningitis have again brought the use of unheated human and animal serum into great prominence and provoked considerable discussion at various pathological meetings.

It would appear to us that the reason why some laboratories have failed hitherto fully to appreciate the value of unheated serum is due to the introduction of "nasgar," a medium which, in our opinion, is a very inferior substitute and one which gained popularity by the fact that it saved the necessity of obtaining serum or exudates with strict aseptic precautions, and so was more convenient for those who were not in direct touch with a hospital or students.

We are, Sir, yours faithfully,

G. T. WESTERN,

LUDWIK RAJCHMAN.

Bacteriological Laboratory, London Hospital, August 23rd, 1916.

\section{THE PSYCHO-PATHOLOGY OF WAR NEUROSES.}

To the Editor of THE LANCET.

SiR, - With regard to Dr. G. Burton-Brown's letter in your issue of Aug. 19th, if he would kindly refer to my article he will see that it is in Case 7's dream that he says : "I ..... rang down full speed ahead." Dr. Burton-Brown would, of course, not expect verbal accuracy in a dream even about technical matters. There was a reason for the patient's use of the word "speed" in his dream, but the explanation would take me beyond the limits of a letter. "What Dr. Burton-Brown thinks I think sailors say has really little to do with what a patient, who was not a sailor, dreams he is saying. I am, Sir, yours faithfully,
M. D. EDER. 